\title{
New Chief Executive Officers' Earnings Forecasts Bias At Their First Year Term And Role Of Financial Analysts: Korean Evidence
}

Chang Seop Rhee, Sejong University, South Korea Boyoung Moon, Dankook University, South Korea

\begin{abstract}
This study investigates newly appointed Chief Executive Officers (CEOs)' earnings forecasts bias at their first year term using listed firm data in Korea. Prior literature reports that new CEOs prefer to report low earnings (big bath or cookie jar accounting) at their first year term for the purpose of income smoothing. However, it is hard to find the studies about new CEOs' earnings forecasts bias at the term of low earnings reporting incentive. We question what earnings forecasts bias they usually have when they are interested in low earnings reporting.

From the empirical tests, we find that newly appointed CEOs tend to provide conservative (negative) forecasts instead of optimistic (positive) forecasts at their first term. Furthermore, we find that greater analyst following helps to relieve the negatively biased earnings forecasts of new CEOs.

This study will contribute to academics and disclosure-related practitioners by documenting about newly appointed CEOs' earnings forecasts bias. We also believe that our empirical evidence will be helpful to market participants when they make a business decisions in case of CEO turnover.
\end{abstract}

Keywords: New CEOs; Management Earnings Forecasts; Forecast Bias; Analysts’ Following

\section{INTRODUCTION}

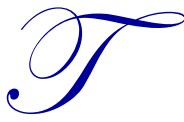

his paper investigates the earnings forecasts bias of newly appointed Chief Executive Officers (CEOs) at the year of CEO change using listed firm data in Korea. CEOs are representatives and supreme decision makers in their firms. It is a general idea that CEOs' unique business philosophy and business idea make a great influence to their firms' culture remarkably. That is why public has an interest in CEOs and news media report the events related CEOs frequently. For instance, when a well-known firm hires new CEO, financial broadcasts analyze the new CEO' capability and predict firm's future performance based on his/her historical records. In Korea, the influence of CEOs is also very powerful. Korean financial news media and Korean financial analysts often report the news related to CEO turnover as a significant event. In other words, newly appointed CEOs cannot avoid a great attention from public at their first term year as much as their influence to the financial market is very powerful.

We are curious about what types of earnings forecasts bias new CEOs have at their first year term. Prior literature reports that new CEOs have an income-decreasing reporting incentive at their first year term for doing big bath or cookie jar accounting (Pourciau, 1993; Francis et al., 1996). Then, they can report incremental incomes smoothly for their overall CEO terms. However, it is difficult to find the studies about new CEOs' earnings forecasts bias at the term of low income reporting incentive. We question what earnings forecasts bias they usually have when they have the low earnings reporting incentive. 
In this situation, newly appointed CEOs may provide either optimistic or conservative earnings forecasts. In terms of optimistic earnings forecasts, they may provide optimistic earnings forecasts at their first year term for satisfying capital market expectation. They can signal their outstanding capability as new CEOs to the capital market using optimistic earnings forecasts (Truman, 1986). On the other hand, in terms of conservative earnings forecasts, they may provide conservative earnings forecasts at their first year term in order to meet or beat the earnings forecasts easily. Then they can signal that they yield higher reporting earnings than their earnings forecasts at the time of low earnings reporting incentive.

As a component of information environment, the role of financial analysts is one of the related issues with management earnings forecasts bias on new CEOs. Financial analysts serve as information intermediaries or information providers in the capital market (Yoo et al, 2013). They are not only the main users of management earnings forecasts but also the prime information suppliers. Some of prior U.S. studies provide evidence that there is a positive association between number of financial analysts and stock trading volume (Hayes, 1998; Irvine, 2001). Under this perspective, the analysts' following is a proxy for the level of information environment, and greater analysts' following implies better information environment which is less information asymmetry in the capital market. We additionally examine the greater financial analysts can reduce the management earnings forecasts bias at new CEOs' first year term.

We provide two pieces of empirical tests by using 493 listed firm observations from 2002 to 2008 fiscal years in Korea. First, we find that newly appointed CEOs tend to provide conservative (negative) forecasts rather than optimistic (positive) forecasts at their first year term. The negative association is consistent with the view that new CEOs have incentives to meet or beat their earnings forecasts rather than to signal optimistic short-term earnings forecasts at the first term year. Furthermore, we find that greater analysts' following relieve the conservative forecasts of newly appointed CEOs. This result suggests that the greater number of financial analysts help to reduce new CEOs' earnings forecasts bias by improving information environment.

This study contributes to the literature in the following ways. First, to our knowledge, there is no previous evidence on the direct negative association between new CEO appointment and management earnings forecasts bias in Korea. We believe that the empirical evidences may shed a light on our understanding of managers' incentives for information disclosure with their tenure. Second, this study provides insight into the effect of analyst coverage on the relation between new CEO appointment and management earnings forecasts bias. We also believe that this study may help market participants to deeply understand the distinctive role of financial analysts in Korea.

The rest of this paper is organized as follow. Section 2 discusses the prior researches and develops our reasoning. Section 3 provides the research design. Section 4 reports sample selection criteria, and the empirical results from the model estimation. Section 5 concludes the paper.

\section{BACKGROUND AND HYPOTHESES DEVELOPMENT}

\subsection{CEO Turnover}

Early study on CEO turnover and managers' self-interest behavior is developed by Moore (1973) and Strong and Meyer (1987). Moore (1973) compares the proportion of income-decreasing discretionary accounting decisions from firms with management changes and from firms with no management change. He reports that the firms with management changes make more income-decreasing discretionary accounting decisions than the firms without management changes. Strong and Meyer (1987) investigate CEOs' reporting decision in case of CEO replacement. They find that new CEOs tend to report low earnings by making write-down decision at their first year term. Dechow and Sloan (1991) argue that preceding CEOs have incentives to maximize their self-interest by saving $R \& D$ expenses at their last year term. The tendency of saving R\&D expenses of preceding CEOs is weaken when they own a large portion of stock option or when new CEOs are appointed by promotion from within their companies. However, Murphy and Zimmerman (1993) do not find strong evidence about the argument that preceding CEOs attempt to save R\&D or advertisement expenses at right before replacement. They argue that newly appointed CEOs at the firms with bad performance do earnings management for reporting low earnings at their first CEO term. 
Pourciau (1993) investigates the association between CEO change and discretionary accounting decisions. She classifies CEO change as routine change or non-routine change. She reports that earnings management is happened more in case of non-routine CEO change than in case of routine CEO change. Especially, she finds that newly appointed CEOs make discretionary accounting decisions for reporting low earnings at the first term. This result is consistent with big bath or cookie jar accounting story of earnings management for the purpose of income smoothing.

\subsection{Management Earnings Forecasts}

Early study of management earnings forecasts are begun by Basi et al. (1976), Ruland (1987), and Jaggi (1980). They study accuracy of management earnings forecasts. They report that the accuracy of analysts' forecasts and management earnings forecasts is not significantly different. However, follow-up studies report that management earnings forecasts are more accurate than analysts' forecasts (Waymire, 1986; Hassell and Jennings, 1986). Hartnett (1993) studies management earnings forecasts bias using Australia firm data, and he finds that Australian firm managers tend to forecast earnings optimistically. Furthermore, many studies have documented that managers release the biased earnings forecasts under various incentive-related factors. Those factors may include boosting market expectations (Rogers and Buskirk 2006), facilitating equity issuance (Lang and Lundholm 2000), and reducing expected legal costs (Skinner 1994).

\subsection{Hypotheses Development}

Right after CEO replacement, market participants eye on new CEO. As the market participants look for the positive prediction of the firms' performance from new CEOs, no optimistic forecasts of the new CEOs would be disappointing news to them. Therefore, newly appointed CEOs may provide optimistic earnings forecasts for satisfying market expectation and signaling their confidence about firm performance at the point of receiving noticeable attention from public.

On the other hand, as discussed in the previous section, new CEOs have incentives of big bath or cookie jar accounting at their first year term. They attempt to report low earnings at the year for achieving gradual increasing earnings during overall CEO tenure. In the same vein, CEO may also forecast earnings more conservatively in order to meet or beat their earnings forecasts easily. Even though their reporting earnings is low due to big bath or cookie jar accounting, they can send a positive signal to the capital market that a least they meet or beat at their earnings forecasts. Yet, it is an empirical question whether they forecast earnings conservatively than the lowly reported earnings at that time.

Thus, it is hard to discern the exact direction of association between new CEO appointment and management earnings forecasts bias. Hence, we set the first hypothesis is as follows:

H1: New CEO appointment is associated with management earnings forecasts bias.

Financial analysts serve as information intermediaries or information providers in the capital market (Yoo et al, 2013). Yoo et al (2003) use the number of analyst following as a proxy of the level of information environment. As information environment is improved, the information asymmetry between firms and investors is reduced. In other words, greater analysts' following helps to improve information environment and eventually it moderates management earnings forecasts bias. In the second hypothesis, we test whether the greater analysts' following affects the management earnings forecasts bias.

H2: Analysts' following reduces management earnings forecasts bias at the first CEO year term. 


\section{RESEARCH METHODOLOGY}

\subsection{CEO Turnover}

We collect CEO information from quarterly reports from Data Analysis, Retrieval and Transfer System (DART) of Financial Supervisory Service in Korea. We define a firm's CEO who is the highest rank among fulltime directors having a president status of the company. If the CEO is unmatched when comparing the first quarterly reports of this year to the first quarterly reports of the last year, we consider that CEO is replaced.

\subsection{Management Earnings Forecasts Bias}

We measure management earnings forecasts bias using operating income. The bias is the difference of forecasted operating income and reported operating income divided by reported operating income. The positive $(+)$ bias indicates that the forecasted operating income by managers is higher than reported operating income, meaning the managers provide optimistic earnings forecasts than reporting earnings. On the other hand, the negative (-) bias indicates that forecasted operating income by managers is lower than reported operating income, meaning the managers provide conservative earnings forecasts than reporting earnings.

$$
M B I A S=\frac{\text { (forecasted operating income-reported operating income) }}{\text { reported operating income }}
$$

\subsection{Model}

To test our hypothesis 1 on the association between new CEO appointment and management earnings forecasts bias, we construct an indicator variable (NEWCEO) that equals to 1 if new CEO is appointed, 0 otherwise. We run a regression on management forecasts bias (MBIAS), new CEO appointment (NEWCEO), and control variables as follows:

$$
M B I A S=\beta_{0}+\beta_{1} N E W C E O+\beta_{2} S I Z E+\beta_{3} B M+\beta_{4} D M+\beta_{5} H O R+\beta_{6} O I V O L
$$

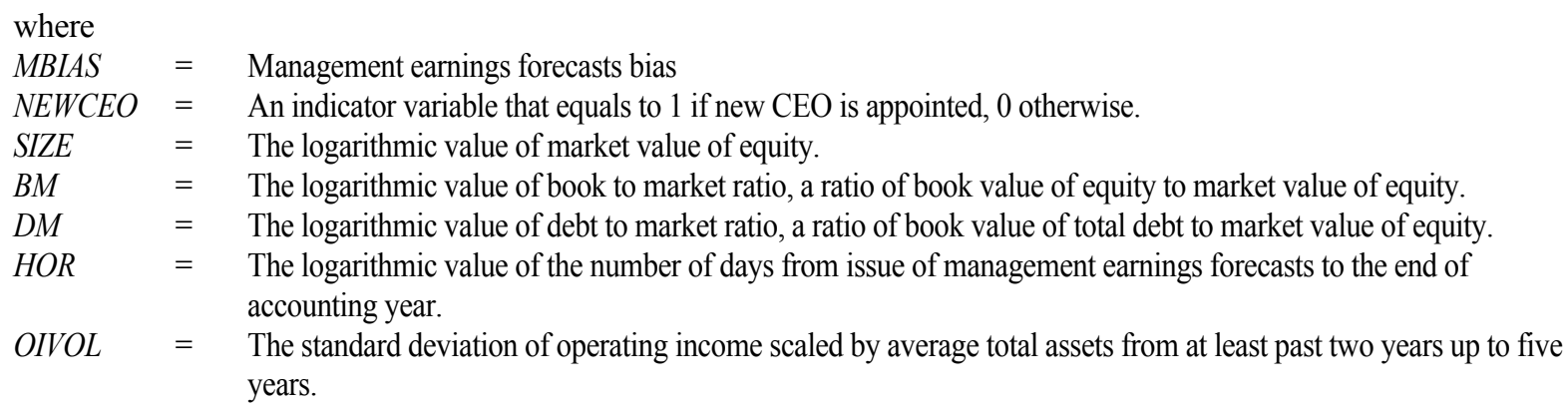

To test our hypothesis 2, we additionally include the number of analysts' following (NANALYST) and the interaction term between the number of analysts' following and new CEO appointment as follows $(N E W C E O * N A N A L Y S T)$ :

$M B I A S=\beta_{0}+\beta_{1} N E W C E O+\beta_{2} N A N A L Y S T+\beta_{3} N E W C E O * N A N A L Y S T+\beta_{4} S I Z E+\beta_{5} B M+\beta_{6} D M+\beta_{7} H O R+$ $\beta_{8} O I V O L$

(Model 2) 


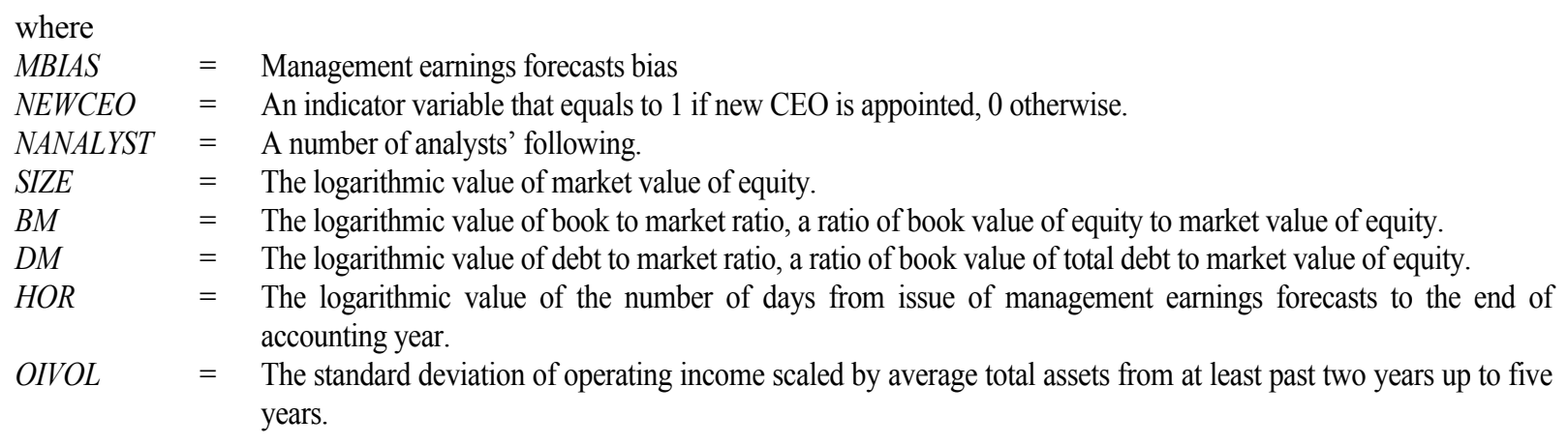

We use control variables which can affect management earnings forecasts bias as follows. To control firm size (SIZE), we take the logarithmic value of market value of equity. According to prior research, managers provide more credible earnings forecasts as their firm size (SIZE) is bigger (Baninski \& Hassell, 1997). Book to market ratio $(B M)$ is a proxy of firm's performance and future growth, and therefore managers are likely to provide more accurate earnings forecasts as $B M$ ratio is higher (Bamber \& Cheon, 1998). Kwon et al. (2009) state that the accuracy of management earnings forecasts is lower as debt ratio $(D M)$ increases. Choi \& Ziebart (2000) explain that forecasting error is increased as the standard deviation of operating income $(O I V O L)$ is higher and the number of days from issuance of management earnings forecasts to the end of accounting year $(H O R)$ is longer due to higher uncertainty.

\subsection{Sample Selection}

Our empirical tests are based on 493 Korean firm-year observations from 2002 to 2008 fiscal year, which satisfy the following selection criteria: (1) fiscal year ended December 31, (2) firms in non-financial industry, (3) $\mathrm{CEO}$ is replaced during the period, (4) Management earnings forecasts are provided, and (5) all the risk proxies available.

To collect management forecasts data, we use a keyword search to obtain management earnings forecasts data from Korea Investor's Network for Disclosure system of the Korean Exchange (KRX). The collection process of management forecasts requires management forecasts to be entitled 'Interim Report on Business Performance (Fair Disclosure)' which includes operating income. Since the initial raw data mainly consist of annual (one-yearahead) management forecasts, we omit quarterly, biannual, or long-term forecasts from management forecasts data. We also exclude the forecasts that are subsequently revised during the same disclosing period. Consequently, the final hand-collected data of management earnings forecasts represent the finally revised annual earnings disclosure.

Table 1 shows the frequency distribution of the final firm-year observations for our empirical tests. We present the observations by fiscal year in Panel A and the observations by industry group in Panel B.

Table 1. Distribution of observations by Year and Industry

Panel A Sample Distribution by Year

\begin{tabular}{|c|c|c|}
\hline 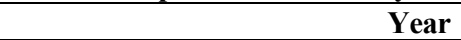 & \# of obs. & $\%$ \\
\hline 2002 & 26 & 5.27 \\
\hline 2003 & 68 & 13.79 \\
\hline 2004 & 70 & 14.20 \\
\hline 2005 & 73 & 14.81 \\
\hline 2006 & 77 & 15.62 \\
\hline 2007 & 86 & 17.44 \\
\hline 2008 & 93 & 18.87 \\
\hline Total & 493 & 100.00 \\
\hline
\end{tabular}


(Table 1 continued)

Panel B Sample Distribution by Industry

\begin{tabular}{lcc}
\hline \multicolumn{1}{c}{ Industry } & \# of obs. & \% \\
\hline Manufacturing & 273 & 55.38 \\
Electricity, gas, steam and water supply & 2 & 0.41 \\
Construction & 78 & 15.82 \\
Wholesale and retail trade & 45 & 9.13 \\
Transportation & 26 & 5.27 \\
Publication, Broadcasting communication, and information services & 17 & 3.45 \\
Professional, scientific and technical activities & 44 & 8.92 \\
Others & 8 & 1.62 \\
Total & $\mathbf{4 9 3}$ & $\mathbf{1 0 0}$ \\
\hline
\end{tabular}

Note: This table shows the frequency distribution of 493 firm-year observations used in the main hypotheses tests. Industry definitions are based on the KSIC-9 (the Korea Standard Industrial Classification).

\section{EMPIRICAL RESULTS}

\subsection{Descriptive Statistics}

Table 2 provides descriptive statistics about management earnings forecasts bias, new CEO appointment, and other variables. The mean of management earnings forecasts bias (MBIAS) and new CEO appointment (NEWCEO) is 0.599 and 0.183 respectively. The mean of number of analysts' following (NANALYST) is 6.272, and distribution of the other control variables are generally consistent with prior Korean studies.

Table 2. Descriptive Statistics of the Main Variables

\begin{tabular}{lcccccccccc}
\hline Variables & Mean & $\begin{array}{c}\text { Std. } \\
\text { Dev. }\end{array}$ & $\mathbf{5 \%}$ & $\mathbf{1 0 \%}$ & $\mathbf{2 5 \%}$ & MED. & $\mathbf{7 5 \%}$ & $\mathbf{9 0 \%}$ & $\begin{array}{c}\mathbf{9 5 \%} \\
\text { N. of } \\
\text { Obs }\end{array}$ \\
\hline MBIAS & 0.599 & 2.935 & -0.432 & -0.227 & -0.031 & 0.106 & 0.490 & 1.573 & 3.367 & 493 \\
NEWCEO & 0.183 & 0.378 & 0 & 0 & 0 & 0 & 0 & 1 & 1 & 493 \\
NANALYST & 6.272 & 6.8605 & 0 & 0 & 0 & 4 & 11 & 17 & 20 & 493 \\
SIZE & 8.678 & 1.562 & 6.531 & 6.867 & 7.286 & 8.446 & 9.869 & 10.844 & 11.324 & 493 \\
BM & 1.481 & 2.171 & 0.224 & 0.302 & 0.566 & 0.936 & 1.48 & 2.604 & 3.858 & 493 \\
DM & 0.484 & 0.181 & 0.148 & 0.213 & 0.366 & 0.499 & 0621 & 0.691 & 0.751 & 493 \\
HOR & 272 & 99 & 39 & 64 & 263 & 313 & 335.5 & 348 & 356 & 493 \\
OIVOL & 0.034 & 0.035 & 0.007 & 0.010 & 0.016 & 0.024 & 0.039 & 0.064 & 0.084 & 493 \\
\hline
\end{tabular}

Note: This table reports descriptive statistics of the mean, median, and distributions of main variables used in this paper. All variables are winsorized at top and bottom one-percentile of the pooled data.

\subsection{Univariate Analysis}

Table 3 presents the Pearson correlations among management earnings forecasts bias (MBIAS), new CEO appointment (NEWCEO), and other variables. In this table, $N E W C E O$ is significantly and negatively correlated with $M B I A S$. It implies that newly appointed CEOs tend to forecast earnings conservatively. However, given that NEWCEO is also significantly correlated with several control variables (NANALYST and HOR), the implication of the univariate result appears to be limited. Therefore, we perform the multivariate regression analyses to examine the overall association between new CEO appointment (NEWCEO) and management earnings forecasts bias (MBIAS) coupled with control variables. Most control variables are correlated each other as expected. 
Table 3. Univariate Correlation Among The Main Variables

\begin{tabular}{|c|c|c|c|c|c|c|c|}
\hline & MBIAS & NEWCEO & NANALYST & $S I Z E$ & $B M$ & $D M$ & HOR \\
\hline$N E W C E O$ & $-0.096^{* *}$ & 0 & & & & & \\
\hline NANALYST & $-0.119 * * *$ & $-0.075^{*}$ & & & & & \\
\hline SIZE & $0.091 * *$ & -0.014 & $0.719 * * *$ & & & & \\
\hline$B M$ & $0.097 * *$ & 0.000 & $-0.248 * *$ & $-0.157 * * *$ & & & \\
\hline$D M$ & 0.006 & 0.052 & $0.286^{* * *}$ & $0.286^{* *}$ & 0.007 & & \\
\hline$H O R$ & 0.056 & $-0.083^{*}$ & $0.209^{* * *}$ & $0.209 * * *$ & $-0.130 * * *$ & -0.044 & \\
\hline OIVOL & 0.002 & -0.073 & $-0.241 * * *$ & $-0.241 * * *$ & 0.019 & -0.021 & $-0.214 * * *$ \\
\hline
\end{tabular}

Note: This table presents Pearson correlation between the management forecast bias, management forecast accuracy, CEO turnover, number of analysts' following and other control variables. ${ }^{* *}, * *$ and $*$ denote the significance level (two-tailed) at $1 \%, 5 \%$ and $10 \%$ or less, respectively.

\subsection{Multivariate Analysis}

Table 4 presents the results from the multivariate regression of new CEO appointment on management earnings forecasts bias. The first column in table 4 for model (1) shows that management earnings forecasts bias $(M B I A S)$ is negatively associated with new CEO appointment (NEWCEO) at five percent or less of significance level $(\mathrm{t}-\mathrm{stat}=-2.04)$. This negative association suggests that newly appointed CEO tends to forecast earnings conservatively at their first year term, supporting the hypothesis 1 . The second column in table 4 for model (2) shows how the association between new CEO appointment (NEWCEO) and management earnings forecasts bias varies with respect to the number of analysts' following, examining the coefficient of NEWCEO*NANALYST. The relation between $N E W C E O$ and NBIAS is still negatively significant in model (2).

However, we find that the interaction term $\left(N E W C E O^{*} N A N A L Y S T\right)$ is positively associated with management earnings forecasts bias at ten percent or less of significance level $(\mathrm{t}-\mathrm{stat}=1.80)$, and this results imply that the conservative forecasts bias of managers is diminished as the number of analysts' following increases. In case of greater financial analysts, the coefficient of $N E W C E O$ on management earnings forecasts bias is weaker to -1.144 $(-1.245+0.101)$ from -1.245 . The explanation of the positive association of the interaction term is that greater analysts' following improve information environment and eventually it helps to control managers' biased earnings forecasts. In other words, new CEOs feel pressure to provide biased earnings forecasts to the market participants in the improved information environment.

In order to test multicolliearity problem, we report variance inflation factor (VIF). The maximum VIF of model (1) and (2) are 2.00 and 3.92 respectively. Since maximum VIF is lower than 10 , the possibility of multicollinearity problem is quite low we consider. 
Table 4. Results Of Multivariate Regression Analysis

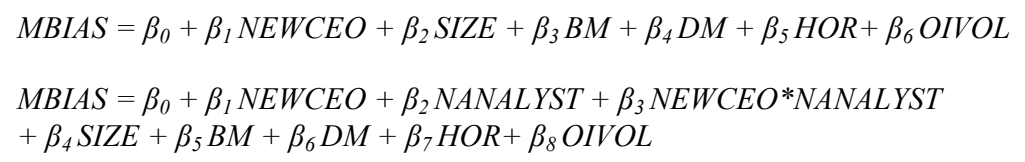

\begin{tabular}{|c|c|c|c|c|}
\hline \multirow{2}{*}{$\begin{array}{l}\text { Independent } \\
\text { Variable }\end{array}$} & \multicolumn{2}{|c|}{ Model 1} & \multicolumn{2}{|c|}{ Model 2} \\
\hline & Estimate & t-value & Estimate & t-value \\
\hline Intercept & 2.525 & 1.04 & 1.948 & 0.77 \\
\hline NEWCEO & $-0.684 * *$ & -2.04 & -1.245 & -2.79 \\
\hline NANALYST & & & -0.049 & -1.45 \\
\hline$N E W C E O * N A N A L Y S T$ & & & $0.101 *$ & 1.80 \\
\hline SIZE & -0.145 & -1.37 & -0.013 & 0.08 \\
\hline$B M$ & 0.072 & 1.11 & 0.057 & 0.85 \\
\hline$D M$ & 0.276 & 0.32 & 0.088 & 0.10 \\
\hline$H O R$ & 0.096 & 0.23 & 0.109 & 0.47 \\
\hline OIVOL & 0.698 & 4.07 & 0.646 & 0.16 \\
\hline Industry \& Year & \multirow{2}{*}{\multicolumn{2}{|c|}{$\begin{array}{l}\text { Fixed } \\
21.72 \%\end{array}$}} & \multicolumn{2}{|c|}{ Fixed } \\
\hline Ajd. $\mathrm{R}^{2}$ & & & \multirow{2}{*}{\multicolumn{2}{|c|}{$\begin{array}{l}13.69 \% \\
493\end{array}$}} \\
\hline \# of Samples & \multicolumn{2}{|c|}{493} & & \\
\hline Max VIF & \multicolumn{2}{|c|}{2.00} & \multicolumn{2}{|c|}{3.92} \\
\hline
\end{tabular}

Note: This table presents the mean coefficient estimators of year-by-year regression for new CEO appointment (NEWCEO) on management earnings forecasts bias $(M B I A S)$. ${ }^{* *},{ }^{* *}$ and $*$ denote the significance level (two-tailed) at $1 \%, 5 \%$ and $10 \%$ or less, respectively.

\subsection{Additional analyses}

We conduct additional analyses to test the effect of analysts' following on newly appointed CEOs' earnings forecasts bias at their first year term. We make two groups; firms with greater number of analysts' following (Greater NANALYST ) and firms with lesser number of analysts' following (Lesser NANALYST). In Table 2 of descriptive statistics, median of number of analysts' following (NANALYST) is 4 . Therefore, we classify the group of firms with greater analysts' following if the number of analysts' following is greater than or equal to 4 . On the other hand, we classify the group of firms with lesser analysts' following if number of analysts' following if less than 4 . The first column of Table 5 is the multivariate result of the group of firms with greater analysts' following. It shows that the coefficient of $N E W C E O$ is insignificantly negative ( $\mathrm{t}$-stat $=-0.23$ ). We do not find strong evidence that newly appointed CEOs tend to provide conservative earnings forecasts in case of greater analysts' following. On the other hand, in the second column of Table 5 which is multivariate result of the group of firms with lesser analysts' following, we find very significant evidence that newly appointed CEOs are likely to provide conservative earnings forecasts $(\mathrm{t}$-stat $=-2.33)$. Taken together, the overall results in Table 5 suggests that the newly appointed CEOs' conservative earnings forecasts bias is weaker when the number of analysts' following is greater, and it supports the results in table 4. 
Table 5. Results Of Additional Analysis

Model (1)

MBIAS $=\beta_{0}+\beta_{1} C E O T O+\beta_{2} S I Z E+\beta_{3} B M+\beta_{4} D M+\beta_{5} H O R+\beta_{6} O I V O L$

(Model 1)

\begin{tabular}{|c|c|c|c|c|}
\hline \multirow{2}{*}{$\begin{array}{l}\text { Independent } \\
\text { Variable }\end{array}$} & \multicolumn{2}{|c|}{ Greater NANALYST } & \multicolumn{2}{|c|}{ Lesser NANALYST } \\
\hline & Estimate & t-value & Estimate & t-value \\
\hline Intercept & -0.002 & 0.00 & 1.227 & 0.30 \\
\hline NEWCEO & -0.065 & -0.23 & $-1.447 * * *$ & -2.33 \\
\hline SIZE & -0.077 & -0.77 & 0.258 & 0.81 \\
\hline$B M$ & 0.149 & 1.16 & 0.095 & 0.88 \\
\hline$D M$ & 0.373 & 0.46 & -0.221 & -0.14 \\
\hline HOR & 0.088 & 0.30 & 0.008 & 0.02 \\
\hline OIVOL & 1.696 & 0.51 & 2.171 & 0.26 \\
\hline Industry \& Year & \multirow{2}{*}{\multicolumn{2}{|c|}{$\begin{array}{l}\text { Fixed } \\
31.62 \%\end{array}$}} & \multicolumn{2}{|c|}{$\begin{array}{l}\text { Fixed } \\
15,43 \%\end{array}$} \\
\hline Adj, R2 & & & & \\
\hline \# of Samples & \multicolumn{2}{|c|}{255} & \multicolumn{2}{|c|}{238} \\
\hline Max VIF & \multicolumn{2}{|c|}{3.54} & \multicolumn{2}{|c|}{2.12} \\
\hline
\end{tabular}

Note: This table presents the mean coefficient estimators of year-by-year regression for new CEO appointment (NEWCEO) on the management earnings forecasts bias $(M B I A S)$. We make two groups; firms with greater number of analysts' following and firms with lesser number of analysts' following. The median of number of analysts' following (NANALYST) is 4 . The first column of Greater NANALYST group shows the multivariate result if NANALYST is greater than or equal to 4. The second column of Lesser NANALYST group shows that the multivariate results if NANALYST is less than $4 . * * *, * *$ and * denote the significance level (two-tailed) at $1 \%, 5 \%$ and $10 \%$ or less, respectively.

\section{CONCLUSION}

This study investigates newly appointed CEOs' earnings forecasts bias at their first year term using Korean listed firms' observations. At the first year term, not only the new CEOs receive a great attention from market participants but also they have an incentive of reporting low income. In this circumstance, the CEOs may provide optimistic earnings forecasts to satisfy short-term market expectation, or they may provide conservative earnings forecasts to meet or beat their earninigs forecasts easily. Using 493 Korean firm-year observations, we find that there is a negative association between new CEO appointment and management earnings forecasts bias. We interpret this result that newly appointed CEOs have more incentive to provide conservative earnings forecasts at their first year in order to meet or beat the earnings forecasts easily. Furthermore, we find that greater analysts' following relieve the conservative earnings forecasts bias of new CEOs. This implies that financial analysts play a role of improving information environment and of reducing the biasness of management earnings forecasts.

Nonetheless, we acknowledge that our findings may have following caveats. First, there may be other omitted factors which bias our empirical results. In addition, we cannot rule out the possibility that our results largely depend on measurement criteria or time period. Second, our firm-year observations are constrained by the availability of analysts' earnings forecasts, and thereby it may contain a bias that our sample is toward relatively large firms. Therefore, it is challenging to say that our results can be generalized into a broader set of firms. Third, in this study, we could not distinguish the voluntariness of CEO turnover due to data limitation. Whether preceding CEOs are replaced voluntarily or non-voluntarily is important because it may affect new CEOs' character. We view the exploration about the effect of voluntariness of CEO turnover on management earnings forecasts bias as a rich avenue for further research.

Despite these caveats, we believe that our study sheds some lights on the new CEOs' earnings forecasts bias at their first year term. Specifically, our empirical results help academics and stock market practitioners to understand the capital market effect of CEO turnover and the role of financial analysts in Korean market. 


\section{AUTHOR INFORMATION}

Chang Seop Rhee $\left(1^{\text {st }}\right.$ author) is an assistant professor of School of Business at Sejong University in Korea. Research interests include International Financial Reporting Standard, equity valuation, management earnings forecasts, and other financial \& managerial accounting issues.E-mail: crhee2@gmail.com

Boyoung Moon (corresponding author) is an assistant professor of School of Business Administration at Dankook University in Korea. Research interests include equity valuation, financial accounting, and auditing. E-mail: bymoon@dankook.ac.kr

\section{REFERENCES}

Baginski, S. P., \& Hassell, J. M. (1997). Determinants of management forecast precision. The Accounting Review, 72(April), 303-313.

Bamber, L. S. \& Y. S. Cheon. (1998). Discretionary management earnings forecast disclosures: antecedents and outcomes associated with forecast venues and forecast specificity choices. Journal of Accounting Research, 36(Autumn), $167-190$.

Basi, B.A., J. C. Kenneth \& D. T. Richard. (1976). A comparison of the accuracy of corporate and security analysts' forecasts of earnings. The Accounting Review, 51(April): 244-254.

Choi, J. H. \& Ziebart, D. (2000). A reexamination of bias in management earnings forecasts. University of Illinois.

Dechow, P. M., \& R. G. Sloan. (1991). Executive incentives and the horizon problem. Journal of Accounting and Economics, 14(1), 51-89.

Francis, J., D. Hanna \& L. Vincent. (1996). Causes and effects of discretionary asset write-offs. Journal of Accounting Research, 34(supplement), 117-134.

Hartnett, N. A. (1993). Corporate financial forecast accuracy: an Australian study. International Journal of Accounting, $28,248-258$.

Hassell, J. \& R. Jennings. (1986). Relative forecasts accuracy and the timing of earnings forecast announcement. The Accounting Review, 61(January), 58-75.

Hayes, R. (1998). The impact of trading commission incentives on analysts' stock coverage decisions and earnings forecasts. Journal of Accounting Research, 36, 299-320.

Irvine, P. (2001). Do analysts generate trade for their firms? Evidence from the Toronto stock exchange. Journal of Accounting and Economics, 30, 209-226.

Jaggi, B. (1980). Further evidence on the accuracy of management forecasts vis-à-vis analysts' forecasts. The Accounting Review, 54(January), 96-101.

Kwon, S., D. Lee., \& M. Hwang. (2009). The accuracy of management earnings forecasts after adopting regulation fair disclosure. Korean Accounting Review, 34, 107-141. [Printed in Korean]

Lang, M. H., \& R. J. Lundholm. (2000). Voluntary disclosure and equity offerings: Reducing information asymmetry or hyping the stock? Contemporary Accounting Research, 17(4), 623-662.

Moore, M. (1973). Management change and discretionary accounting decisions. Journal of Accounting Research, 11(1), 100-107.

Murphy, K. J., \& J. Zimmerman. (1993). Financial performance and surrounding CEO turnover. Journal of Accounting and Economics, 16(1-3), 273-315.

Pourciau, S. (1993). Earnings management and nonroutine executive changes. Journal of Accounting and Economics, 16(1-3), 317-336.

Rogers, J., \& A. Buskirk. (2006). Management forecasts bundled with negative earnings surprises: credibility-building versus opportunism. Working Paper, University of Chicago.

Ruland, W. (1987). The accuracy of forecasts by management and by financial analysts. The Accounting Review, 53(April), 439-447.

Skinner, D. (1994). Why firms voluntarily disclose bad news. Journal of Accounting Research, 32(1), 38-60.

Strong, J. S., \& J. R. Meyer. (1987). Asset writedowns: managerial incentives and security returns. Journal of Finance, 42(3), 643-661.

Yoo, G-song., Cha, S. M., Yoo, Y. K., \& Rhee, C. S. (2013). Management earnings forecasts and cost of equity capital: Korean evidence. Korean Accounting Review, 38(1), 209-243.

Waymore, G. (1986). Additional evidence on accuracy of analyst forecasts before and after voluntary management earnings forecasts. The Accounting Review, 61(January), 129-142. 